Annals of Plant Sciences

ISSN: 2287-688X

OPEN ACCESS

Research Article

www.annalsofplantsciences.com

\title{
Assessment of genetic diversity of Canthium parviflorum Lam by RAPD and ISSR markers
}

Sirigiri Chandra Kala ${ }^{1}$, K.V.N. Ratnakar Reddi ${ }^{2}$, Akila Chandra Sekhar ${ }^{3}$, Puli Chandra Obul Reddy $^{4}$, Kokkanti Mallikarjuna*

${ }^{1 *}$ Department of Botany \& Microbiology, Acharya Nagarjuna University, Nagarjuna Nagar, Guntur, Andhra Pradesh, India.

2,3Molecular Genetics and Functional Genomics Laboratory, Department of Biotechnology, School of Life Sciences,

Yogi Vemana University, Kadapa, Andhra Pradesh.

${ }^{4}$ Plant Molecular Biology Laboratory, Department of Botany, School of Life Sciences, Yogi Vemana University, Kadapa, Andhra Pradesh, India.

Received: 10/6/2017; Accepted:10/27/2017

Abstract: Canthium parviflorum Lam is an important medicinal plant widely used in traditional systems of medicine with propagation limitations. In the present work, we are reporting the genetic diversity analysis of naturally occurring and in vitro grown plants by RAPD and ISSR markers. The plants developed on MS medium supplemented with BA $(2 \mathrm{mg} / \mathrm{l})$ and NAA $(0.5 \mathrm{mg} / \mathrm{l})$ using nodal and leaf explants were used along with plants present in five different geographical areas. Genetic diversity analysis using DNA based markers, RAPD and ISSR indicated that considerable genetic variations are present in naturally occurring plants. It is also indicated that tissue culture plants and their wild relatives show genetic similarity by grouping into one clad. The amplification products of the regenerated plants showed similar banding patterns to that of the mother plant thus demonstrating the homogeneity of the micropropagated plants. The variations observed in naturally occurring plants could be due to the impact of local environmental factors and accumulation of mutations in the course of evolution. This is the first report on genetic diversity of Canthium plant populations.

Keywords: Canthium parviflorum, natural plant populations, tissue culture plants, genetic diversity, RAPD, ISSR.

\section{Introduction}

The Canthium parviflorum belonging to the family Rubiaceae is well known for its various medicinal uses in India. The leaves and fruits are edible. They are astringent and effective against cough and indigestion (Kala et al., 2012). Leaves and roots of this plant are used as astringent, diuretic, febrifuge, anti-dysentric, anti-spasmodic, anti-helmintic, antidiarrhoeal and anti-leucorrhoea (Warrier et al., 1994). In ayurvedic system of medicine, it is used as laxative and to cure gout. Canthium as herbal medicine is used for the treatment of diabetes among major tribal groups in Southern Tamilnadu (Ayyanar et al., 2008). Traditionally the roots and leaves were used to cure vitiated conditions of Kapha in fever and constipation (Kirtikar et al., 2001). Canthium parviflorum plant is having seed germination problems and is frequently attacked by Meliola fungi (Hosagoudar and Archana 2009). Since Canthium parviflorum is highly important medicinal plant with propagation limitations, studies on in vitro propagation and conservation needs to be carried out to make the plant available as and when needed. It is well known that in vitro stress affects the genetic stability of the plants and followed by synthesis of rare secondary metabolites (Thomas et al., 2009). It is also important to know genetic

\section{${ }^{*}$ Corresponding Author:}

Dr. Kokkanti Mallikarjuna,

Assistant Professor,

Department of Botany \& Microbiology,

Acharya Nagarjuna University, Nagarjuna Nagar-522510,

Guntur, Andhra Pradesh, India.

E-mail:mallikarjunaanu@gmail.com diversity/similarities of naturally occurring plant populations of Canthium parviflorum. Because this will give scope for evolving strategies for efficient conservation of elite germplasm in breeding programmes. Assessment of genetic diversity will also help in knowing about elite trees with superior traits and further help in correlation of genetic diversity with function. In the current days, it is of value to know the genetic diversity for conserving morphological and biological diversity in a sustainable manner. Hence in the present study, the analysis of genetic diversity of the naturally occurring plants and among tissue cultured plants in relation with its wild relatives is reported.

Among the several markers, RAPD and ISSR have been mostly favoured because of their sensitivity, simplicity and cost effectiveness. Both RAPD and ISSR markers have been successfully applied to detect genetic similarities or differences in tissue cultured plants compared to its wild progenitors (Thomas et al., 2009). The use of two types of markers, which amplify different regions of the genome with multiple amplicons, allows better analysis of genetic stability/variation of tissue culture generated plantlets (Yuan et al., 2009). 
Several authors have used many molecular markers to monitor the plant genetic stability in in vitro regenerated plant species (Kesari et al., 2010) like Withania somnifera (Sinha et al., 2010 and Capparis deciduas (Tyagi et al., 2010). RAPD markers have been widely used for the identification of genetic relationship among populations and between plant populations (Ba et al., 2004, Ferreira et al., 2006, Afzal et al., 2004). It is important to estimate the actual molecular genetic diversity of the existing plants of Canthium parviflorum to identify whether the lack of genetic variability might be the major constraining factor.

\section{Materials and Methods}

In vitro propagation of Canthium parviflorum Healthy green explants like nodal cuttings and leaves were collected from Canthium plant growing in the botanical garden of Acharya Nagarjuna University, Nagarjuna Nagar. These explants were initially washed with running tap water, and then with $5 \%$ labolene for $15 \mathrm{~min}$ followed by washing in running tap water and then 4-5 times with distilled water. These were surface sterilized with $0.1 \%$ mercuric chloride for $2 \mathrm{~min}$ and $70 \%$ alcohol for $15 \mathrm{~s}$ and each surface sterilization was followed by $5-6$ rinses in sterile distilled water (Murashige and Skoog 1962) basal medium supplemented with $30 \mathrm{~g}$ sucrose and agar was used for all experiments. The $\mathrm{pH}$ was adjusted to 5.7 and medium was autoclaved at $15 \mathrm{lbs}$ for $15 \mathrm{~min}$. The medium was supplemented with different concentrations of plant growth regulators like benzyl adenine (BA: $0.5-5$ $\mathrm{mg} / \mathrm{l})$ alone and in combination with $\alpha-$ Napthalene aceticacid (NAA). The explants were then inoculated on agar gelled medium in $25 \times 150 \mathrm{~mm}$ culture tubes and in $150 \mathrm{~cm}$ conical flasks. The cultures were incubated at $24^{\circ} \pm 2^{\circ} \mathrm{C}$, under cool white fluorescent light for $16 \mathrm{~h}$ photoperiod for shoot regeneration and callus initiation. Each treatment contained 20 replicates and each experiment was repeated thrice.

\section{Genomic DNA isolation}

Genomic DNA was isolated from leaf tissue by modified procedure of CTAB method as described by Murray and Thompson 1980. Total genomic DNA was isolated from tender leaves of the eight diverse lines that were collected from different geographical region and two tissue culture generated plants (Table 2, 3) which are maintained in botanical garden in Acharya Nagarjuna University, Guntur. After Rnase treatment, DNA solution was purified with the standard phenol: chloroform method. DNA solution was mixed gently with phenol: chloroform (1:1) and centrifuged at $5000 \mathrm{rpm}$ for 10 minutes at room temperature. The aqueous phase was separated and mixed with an equal volume of chloroform, mixed gently and centrifuged at $5000 \mathrm{rpm}$ for $10 \mathrm{~min}$ at room temperature.
The aqueous phase was separated and mixed with two volumes of absolute ethanol and incubate at $20^{\circ} \mathrm{C}$ for $20 \mathrm{~min}$. The DNA pellet was spooled out with a glass hook; wash with $70 \%$ aqueous ethanol. The DNA pellet was air dried for $20 \mathrm{~min}$ and dissolved in an appropriate volume of sterile TE buffer (10 mM Tris-HCl pH 8.0,1mM EDTA pH 8.0) and stored at $4^{\circ} \mathrm{C}$. The concentration of DNA was determined spectrophotometrically and the quality of DNA was checked through agarose gel electrophoresis. Quantification of the genomic DNA was done on spectrophotometric measurement of UV absorbance at $260 \mathrm{~nm}$. The DNA concentration was calculated using the formula:

\section{DNA concentration $(\mu \mathrm{g} / \mu \mathrm{l})=$ \\ $\underline{O D}_{260} \times 60$ (dilution factor in above) $\times 50 \mu g / \mu l$ 1000}

The ratio of $\mathrm{OD}_{260}$ to $\mathrm{OD}_{280}$ was calculated to check the purity of DNA. DNA samples for analysis were diluted to $10 \mathrm{ng} / \mu \mathrm{l}$ for RAPD and ISSR analysis.

\section{RAPD analysis}

Primers obtained from MWG Biotech Bangalore, India (Table 2), were used to amplify DNA of eight varieties of plants with two tissue regenerated plants along with 6 other diverse lines (which include parental line from Guntur). PCR reaction were carried out in $20 \mu \mathrm{l}$ reaction with $40 \mathrm{ng}$ of DNA as template, 1xPCR buffer (containing $10 \mathrm{mMm}$ Tris $\mathrm{pH} 9.0,50 \mathrm{mM}$ KCL, $1.5 \mathrm{mM} \mathrm{Mgcl} 2), 250 \mu \mathrm{m}$ of each dNTPs, 5 Pico moles of primer and 1 unit of taq DNA polymerase. A 40 cycles PCR reaction is set with all the above mixture programme is set with $95^{\circ} \mathrm{C}$ of initial denaturation for 5 minutes, followed by 40 cycles of $94^{\circ} \mathrm{C}$ of denaturation for 1 minute, $35^{\circ} \mathrm{C}$ of annealing temperature for 1 minute, $72^{\circ} \mathrm{C}$ of extension for 1 minute and finally final extension at $72^{\circ} \mathrm{C}$ for 10 minutes. The amplicons along with 100bp DNA ladder (Bangalore Genie) are resolved in 1.5\% Agarose gel in $0.5 \mathrm{x}$ TBE buffer under constant voltage of $100 \mathrm{~V}$, stained with ethidium bromide, observed and documented in Gel documentation unit (Syngeneic, $\mathrm{UK})$.

\section{ISSR analysis}

ISSR primers were procured from MWG biotech Bangalore, India (Table 3), were used to amplify DNA of eight varieties of Canthium parviflorum selected in the study. PCR reaction were carried out in $20 \mu \mathrm{l}$ reaction with $40 \mathrm{ng}$ of DNA as template, 1xPCR buffer, $250 \mu \mathrm{m}$ of each dNTP, 5 Pico moles of primer and 1unit of Taq DNA pol. A 40 cycles PCR reaction is set with all the above cocktail mixture. Programme is set with $95^{\circ} \mathrm{C}$ for 5 minutes initial denaturation of template DNA, followed by 40 cycles of $94^{\circ} \mathrm{C}$ of denaturation for 1 minute, $45-$ $50^{\circ} \mathrm{C}$ of annealing temperature for 1 minute, $72^{\circ} \mathrm{C}$ 
of extension for 1 minute followed by final extension at $72^{\circ} \mathrm{C}$ for 10 minutes. The amplified product is resolved in $1.5 \%$ Agarose gel stained with ethidium bromide in $0.5 x$ TBE buffer with 100 bpgenei ladder at one end of the gel.

\section{Scoring the data and analysis}

Reproducible bands were scored in all the samples for each of the primer separately. Each amplification was considered as a separate marker. The presence of the amplified product in each variety was recorded as 1 and absence as 0 respectively. All the numerical and taxonomical analysis was conducted using the NTSYS-PC software version 2.0 and cluster analysis of the complete data is done. Similarly matching (SM) dice coefficient values for pair wise comparison between accessions were calculated and a dice coefficient matrix was constructed using the SIMQUAL subroutine. This matrix was subjected to unweighed pairwise group method using arithmetic average analysis (UPGMA) to generate a dendrogram using SAHN sub routine and TREE PLOT of NTSYSPC. The similarity indices were calculated across all possible pair wise comparisons of individuals within and among the population, following the method of Nei and Li (1979). The formula was: SI = 2 NXY / $(\mathrm{NX}+\mathrm{NY})$.

Table 1. Area wise tested samples of Cantbium parviflorum plants for genetic diversity analysis.

\begin{tabular}{ll} 
Line & \multicolumn{1}{c}{ Geographical location } \\
\hline 1 & A.N.U Campus, Guntur Dt. Mother plant for \\
& explants \\
2 & Directly regenerated plant \\
3 & Indirectly regenerated plant \\
4 & Wild plant of Machilipatnam, Krishna Dt. \\
5 & Wild plant of Tirupathi, Chittor Dt. \\
6 & Wild plant of Karimnagar Dt. \\
7 & Wild plant of Kailasagiri, Vizag Dt. \\
8 & Wild plant of Y.V University, YSR Kadapa Dt. \\
\hline
\end{tabular}

Table 2. RAPD and ISSR primers used for genetic diversity analysis of Canthium parviflorum.

\begin{tabular}{|c|c|c|c|c|}
\hline No. & Primer & Sequence $5^{`}-3^{\prime}$ & Annealing Temp* $\left({ }^{\circ} \mathrm{C}\right)$ & Remarks \\
\hline & RAPD & & & \\
\hline 1 & OPA1 & CAGGCCCTTC & $35^{\circ} \mathrm{C}$ & Amplified \\
\hline 2 & OPC2 & GTGAGGCGTC & $35^{\circ} \mathrm{C}$ & Amplified \\
\hline 3 & OPD2 & GGACCCAACC & $35^{\circ} \mathrm{C}$ & Amplified \\
\hline 4 & OPF7 & CCGATATCCC & $35^{\circ} \mathrm{C}$ & Amplified \\
\hline 5 & OPF12 & ACGGTACCAG & $35^{\circ} \mathrm{C}$ & Amplified \\
\hline 6 & OPA12 & TCGGCGATAG & $35^{\circ} \mathrm{C}$ & Not Amplified \\
\hline 7 & OPB6 & TGCTCTGCCC & $35^{\circ} \mathrm{C}$ & Not Amplified \\
\hline 8 & OPC3 & GGGGGTCTTT & $35^{\circ} \mathrm{C}$ & Not Amplified \\
\hline 9 & OPD6 & ACCTGAACGG & $35^{\circ} \mathrm{C}$ & Not Amplified \\
\hline 10 & OPG14 & GGATGAGACC & $35^{\circ} \mathrm{C}$ & Not Amplified \\
\hline 11 & OPG19 & GTCAGGGCAA & $35^{\circ} \mathrm{C}$ & Not Amplified \\
\hline 12 & OPK9 & CCCTACCGAC & $35^{\circ} \mathrm{C}$ & Not Amplified \\
\hline 13 & OPO10 & TCAGAGCGCC & $35^{\circ} \mathrm{C}$ & Not Amplified \\
\hline 14 & OPV11 & CTCGACAGAG & $35^{\circ} \mathrm{C}$ & Not Amplified \\
\hline \multirow[t]{2}{*}{15} & OPX7 & GAGCGAGGCT & $35^{\circ} \mathrm{C}$ & Not Amplified \\
\hline & ISSR & & & \\
\hline 1 & 814 & СТС ТСТ СТС ТСТ СТС ТА & $45^{\circ} \mathrm{C}$ & Amplified \\
\hline 2 & 868 & GAA GAAGAAGAAGAAGAA & $45^{\circ} \mathrm{C}$ & Amplified \\
\hline 3 & 874 & ССС ТСС СТС ССТ ССС Т & $45^{\circ} \mathrm{C}$ & Amplified \\
\hline 4 & 806 & TAT ATA TAT ATA TAT AG & $45^{\circ} \mathrm{C}$ & Not Amplified \\
\hline 5 & 811 & GAG AGA GAG AGA GAG AC & $45^{\circ} \mathrm{C}$ & Not Amplified \\
\hline 6 & 815 & СТС ТСТ СТС ТСТ СТС ТG & $45^{\circ} \mathrm{C}$ & Not Amplified \\
\hline 7 & 818 & CAC ACA CAC ACA CAC AG & $45^{\circ} \mathrm{C}$ & Not Amplified \\
\hline 8 & 822 & ТСТ СТС ТСТ СТС ТСТ СА & $45^{\circ} \mathrm{C}$ & Not Amplified \\
\hline
\end{tabular}

\section{Results and Discussion}

In vitro propagation of Canthium parviflorum Experiments with in vitro propagation using nodal buds and leaves indicated that nodal buds are good explants for regeneration. Among different combinations and concentrations of $\mathrm{BA}$ and NAA tested for shoot induction and multiplication, BA $(2 \mathrm{mg} / \mathrm{l})$ and NAA $(0.5 \mathrm{mg} / \mathrm{l})$ on MS medium are the optimal concentrations for shoot multiplication with nodal explants (Fig 1). Whereas, leaves showed optimal response on MS medium supplemented with BA (3 mg/l) and NAA (0.1 $\mathrm{mg} / \mathrm{l}$ ) (Fig 2). Rooting of microshoots was observed in MS medium supplemented with IBA.

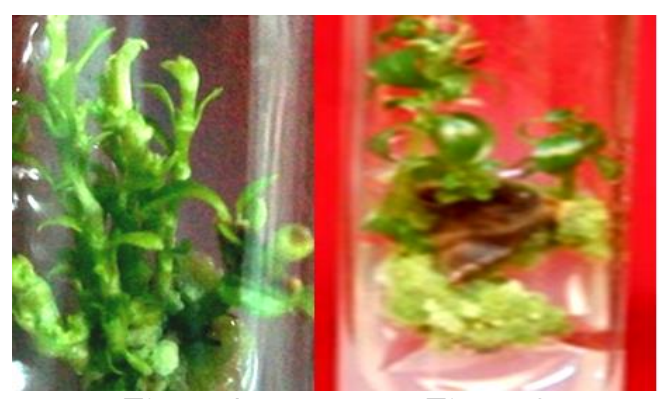

Figure 1

Figure 2

Figure 1. Shoot multiplication of nodal explants grown on MS medium with BA ( $2 \mathrm{mg} / \mathrm{l})$ and NAA $(0.5 \mathrm{mg} / \mathrm{l})$. Figure 2. Response of leaf explants grown on MS medium supplemented with BA $(3 \mathrm{mg} / \mathrm{l})$ and NAA $(0.1 \mathrm{mg} / \mathrm{l})$. 
Genetic diversity analysis using RAPD and ISSR markers

A total of fifteen randomly selected RAPD primers (Table 2) and eight ISSR primers (Table 2) were initially employed to screen and analyze the extent of molecular genetic diversity across six lines of Canthium parviflorum that were collected from various locations of Andhra Pradesh along with two tissue culture generated samplings; to analyse any induced genetic variations due to culture stress. Of fifteen RAPD primers employed, five primers OPA1, OPC2, OPD2, OPF7, and OPF12 (Table 3) amplified across genotypes, showed reproducible and distinct polymorphic amplified products (Fig. 3-7). A total of 29bands were scored of which, $22(76 \%)$ were polymorphic across samples. The five selected primers produced comparatively the maximum number of high intensity bands with minimal smearing, good technical resolution and sufficient variation among diverse lines of selected germplasm, along with tissue culture generated plants. Of eight ISSR primers, three amplified reproducible amplicons, with a maximum of 7 amplicons (874) and 2 amplicons (814). The highest number of amplicons was generated by primer RAPD primer, OPA1 with 9 amplicons (Fig. 3) whereas the least number of bands were produced by RAPD primer OPF7 with 4 amplicons (Fig. 4). In this study, tissue culture generated plants (both directly and indirectly regenerated plants) are showing genetic similarity with their respective parents interms of their strong uniform bands in all RAPD gels (Lane 1, 2, 3 of Figs 3, 4). OPF-12 primer gave high pic value of 0.32 . The reproducibility of the RAPD banding pattern was confirmed by 3 replicated reaction with same primer.

In the present study, aiming to study genetic diversity both germplasm and tissue culture generated Canthium parviflorum the number of alleles generated for individual loci varied from three to nine explaining Polymorphism Index Content (PIC) range between 0.00 to 0.31 in RAPD markers, OPF7 and OPD2 respectively while in ISSR primers PIC with a range of 0.24 to 0.30 for 868 and 874 in ISSR markers respectively.

Table 3. Summary of RAPD and ISSR amplified products from eight mixed samples of Canthium parviflorum

\begin{tabular}{|c|c|c|c|c|c|c|}
\hline No. & Primer & Sequence & $\begin{array}{l}\text { Total No. of } \\
\text { amplicons }\end{array}$ & $\begin{array}{l}\text { Polymorphic } \\
\text { amplicons }\end{array}$ & $\begin{array}{c}\text { Polymorphism } \\
(\%)\end{array}$ & Average $P I C$ \\
\hline & RAPD & & & & & \\
\hline 1. & OPA1 & CAGGCCCTTC & 9 & 8 & 88.9 & 0.27 \\
\hline 2. & $\mathrm{OPC} 2$ & GTGAGGCGTC & 5 & 4 & 80.0 & 0.28 \\
\hline 3. & OPD2 & GGACCCAACC & 7 & 6 & 85.7 & 0.31 \\
\hline 4 & OPF7 & CCGATATCCC & 3 & 0 & 0.0 & 0.00 \\
\hline 5 & $\begin{array}{l}\text { OPF12 } \\
\text { ISSR }\end{array}$ & ACGGTACCAG & 4 & 4 & 100.00 & 0.32 \\
\hline 1. & 814 & СТС ТСТ СТС ТСТ СТС ТА & 2 & 2 & 100.0 & 0.25 \\
\hline 2. & 868 & GAA GAAGAAGAAGAAGAA & 5 & 3 & 60.0 & 0.24 \\
\hline 3. & 874 & ССС ТСС СТС ССТ ССС Т & 7 & 6 & 85.7 & 0.30 \\
\hline
\end{tabular}

Table 4. Distance matrix values based on RAPD and ISSR data (Similarity table) between Canthium parviflorum plants collected from different areas.

\begin{tabular}{|c|c|c|c|c|c|c|c|c|}
\hline & $\begin{array}{l}\text { Guntur wild } \\
\text { Mother plant }\end{array}$ & $\begin{array}{c}\text { Directly } \\
\text { regenerated } \\
\text { plant }\end{array}$ & $\begin{array}{c}\text { Indirectly } \\
\text { regenerated } \\
\text { plant }\end{array}$ & $\begin{array}{c}\text { Kris } \\
\text { hna } \\
\text { Dt. }\end{array}$ & $\begin{array}{c}\text { Chittoor } \\
\text { Dt. }\end{array}$ & $\begin{array}{c}\text { Karimnagar } \\
\text { Dt. }\end{array}$ & $\begin{array}{c}\text { Visakha } \\
\text { patnam Dt. }\end{array}$ & Kadapa Dt. \\
\hline Guntur wild Mother plant & 1.00 & & & & & & & \\
\hline Directly regenerated plant & 0.85 & 1.00 & & & & & & \\
\hline Indirectly regenerated plant & 0.80 & 0.88 & 1.00 & & & & & \\
\hline Krishna Dt. & 0.56 & 0.73 & 0.71 & 1.00 & & & & \\
\hline Chittor Dt. & 0.80 & 0.80 & 0.81 & 0.62 & 1.00 & & & \\
\hline Karimnagar Dt. & 0.66 & 0.66 & 0.76 & 0.62 & 0.67 & 1.00 & & \\
\hline Visakhapatnam Dt. & 0.78 & 0.80 & 0.79 & 0.64 & 0.74 & 0.74 & 1.00 & \\
\hline Kadapa Dt. & 0.59 & 0.61 & 0.64 & 0.60 & 0.55 & 0.60 & 0.67 & 1.00 \\
\hline
\end{tabular}



Where, lanes represent places or sources of plants and DNA, lane-1 A.N.U. campus, mother plant for explants, lane-2 directly regenerated plant, lane-3 indirectly regenerated plant, lane-4 wild plant of Machilipatnam, lane-5 wild plant of Tirupathi, lane6 wild plant of Karimnagar.lane- 7 wild plant of Kailasagiri, and lane- 8 wild plant of Y.V. University, Kadapa.

Figure 3. RAPD profile of Canthium parviflorum using OPA1 primer (Table 2). 


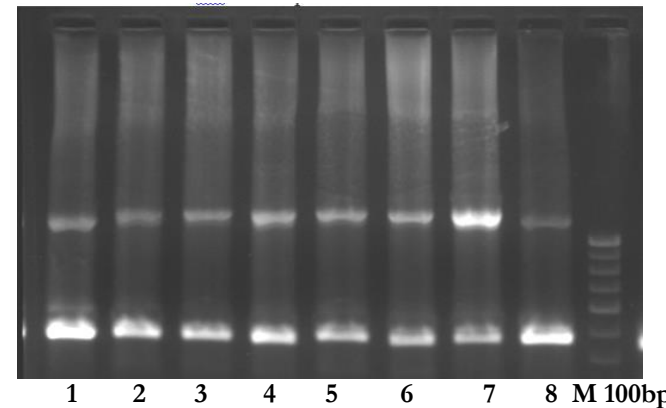

Figure 4. RAPD profile of Canthiumparviflorum using OPC-2 primer (Table 2).

Where, lanes represent places or sources of plants and DNA, lane-1 A.N.U. campus, mother plant for explants, lane-2 directly regenerated plant, lane-3 indirectly regenerated plant, lane-4 wild plant of Machilipatnam, lane- 5 wild plant of Tirupathi, lane6 wild plant of Karimnagar.lane-7 wild plant of Kailasagiri, and lane-8 wild plant of Y.V. University, Kadapa.

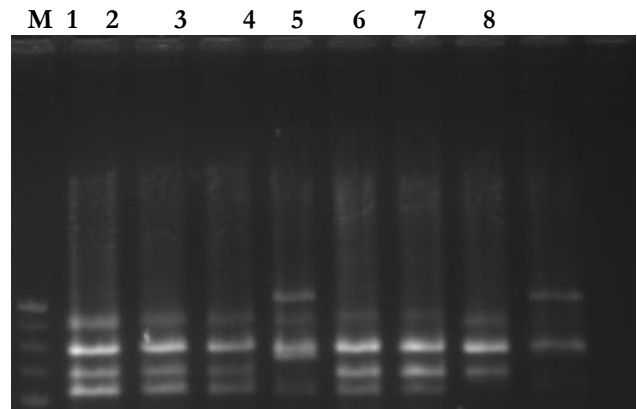

Figure 5. RAPD profile of Canthium parviflorum using OPD2 (c) primer (Table 2).M=100bp.

Where, lanes represent places or sources of plants and DNA, lane- 1 A.N.U. campus, mother plant for explants, lane-2 directly regenerated plant, lane-3 indirectly regenerated plant, lane-4 wild plant of Machilipatnam, lane- 5 wild plant of Tirupathi, lane6 wild plant of Karimnagar.lane-7 wild plant of Kailasagiri, and lane- 8 wild plant of Y.V. University, Kadapa.

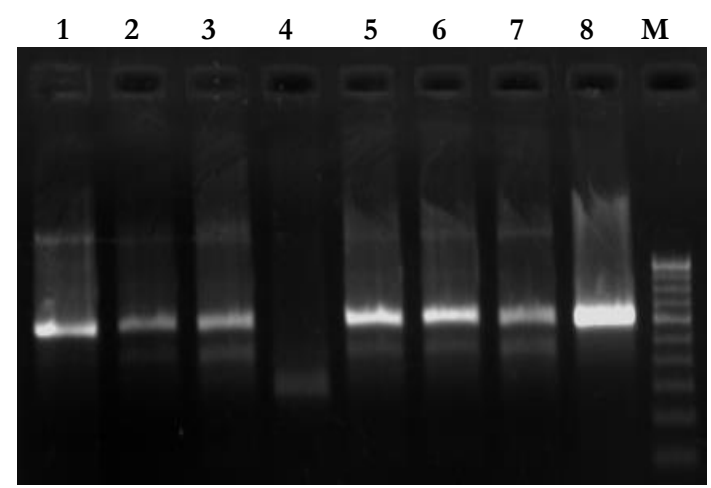

Figure 6. RAPD profile of Canthium parviflorum using OPF-7 primer (Table 2).M=100bp.
Where, lanes represent places or sources of plants and DNA, lane-1 A.N.U. campus, mother plant for explants, lane-2 directly regenerated plant, lane-3 indirectly regenerated plant, lane- 4 wild plant of Machilipatnam, lane- 5 wild plant of Tirupathi, lane6 wild plant of Karimnagar.lane- 7 wild plant of Kailasagiri, and lane- 8 wild plant of Y.V. University, Kadapa.

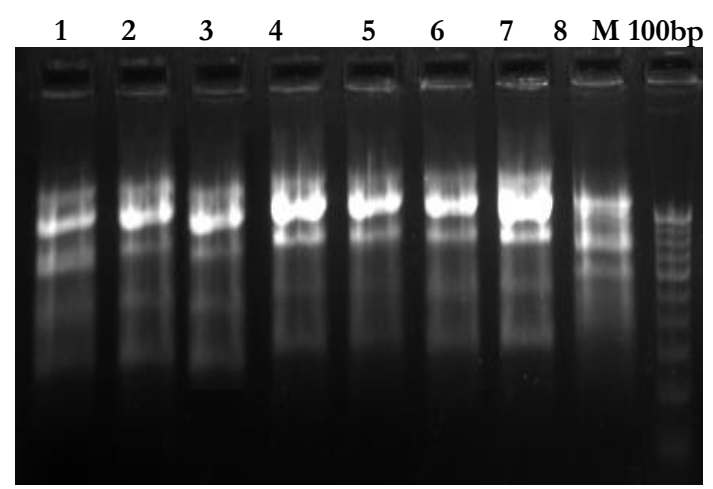

Figure 7. RAPD profile of Canthium parviflorum using OPF12 primer (Table 2).

Where, lanes represent places or sources of plants and DNA, lane- 1 A.N.U. campus, mother plant for explants, lane-2 directly regenerated plant, lane-3 indirectly regenerated plant, lane-4 wild plant of Machilipatnam, lane- 5 wild plant of Tirupathi, lane6 wild plant of Karimnagar.lane-7 wild plant of Kailasagiri, and lane-8 wild plant of Y.V. University, Kadapa.

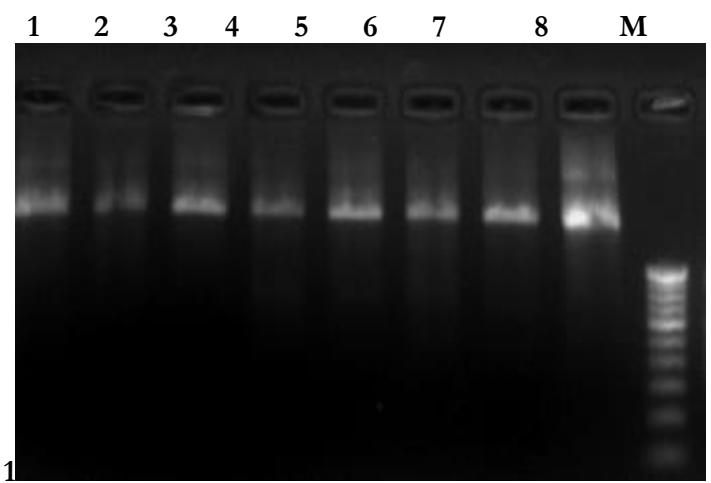

Figure 8. ISSR profile of Canthium parviflorum using ISSR-814 primer (Table 4). M=100bp.

Where, lanes represent places or sources of plants and DNA, lane- 1 A.N.U. campus, mother plant for explants, lane-2 directly regenerated plant, lane-3 indirectly regenerated plant, lane-4 wild plant of Machilipatnam, lane-5 wild plant of Tirupathi, lane6 wild plant of Karimnagar.lane- 7 wild plant of Kailasagiri, and lane- 8 wild plant of Y.V. University, Kadapa. 




Figure 9. ISSR profile of Canthium parviflorum using ISSR-868 primer (Table 4). M=100bp.

Where, lanes represent places or sources of plants and DNA, lane-1 A.N.U. campus, mother plant for explants, lane-2 directly regenerated plant, lane-3 indirectly regenerated plant, lane-4 wild plant of Machilipatnam, lane- 5 wild plant of Tirupathi, lane6 wild plant of Karimnagar.lane-7 wild plant of Kailasagiri, and lane- 8 wild plant of Y.V. University, Kadapa.



Figure 10. ISSR profile of Canthium parviflorum using ISSR-874 primer.M=100bp.

Where, lanes represent places or sources of plants and DNA, lane-1 A.N.U. campus, mother plant for explants, lane-2 directly regenerated plant, lane-3 indirectly regenerated plant, lane-4 wild plant of Machilipatnam, lane- 5 wild plant of Tirupathi, lane6 wild plant of Karimnagar.lane-7 wild plant of Kailasagiri, and lane- 8 wild plant of Y.V. University, Kadapa.

\section{Dendrogram of Canthium parviflorum}

A dendrogram based on Nei's (1979) genetic distance using unweighted pair group method of arithmetic means (UPGMA), indicates the grouping of 8 types of Canthium parviflorum plants into two main clusters, wild type plants from Kadapa district formed one cluster where as A.N.U campus mother plants, tissue cultured plants, wild plants from Tirupathi, Visakhapatnam, Karimnagar, and Krishna districts formed another cluster. Wild type Canthium parviflorum plants of Kadapa remained as distinct and different from other plants. Whereas cluster (2) is again divided into five sub clusters, of which fifth sub cluster comprising tissue cultured plants and their A.N.U. Campus, Guntur mother plants presence of all of them in one sub cluster indicates the less or lack of genetic diversity among them. The same can be evidenced from summary table (Table 3) distance matrix values of RAPD/ISSR data. This segregation of wild types of plants belonging into different areas into different sub clusters indicates the level and extent of genetic variation present in them. Among them, collections from the Kadapa district are more distinct from that of the other collections of Canthium parviflorum in the wild, indicating more genetic diversity.

Figure 11. Dendrogram derived from UPGMA cluster analysis using Dice Coefficient of RAPD and ISSR based markers in Canthium parviflorum plants.

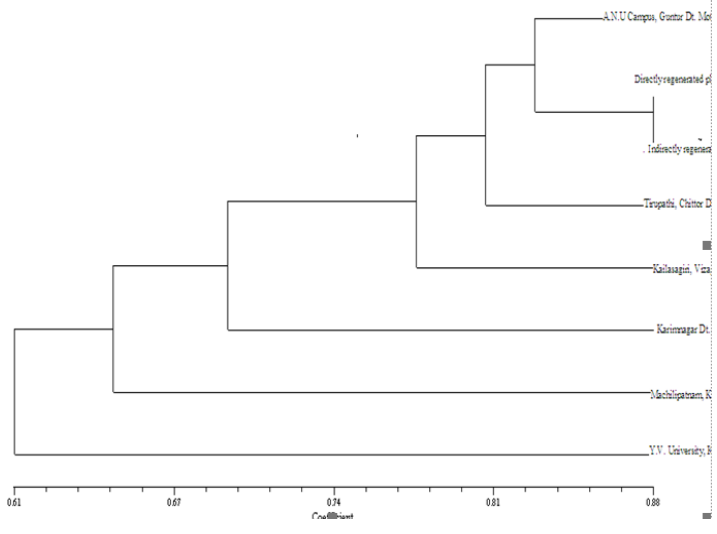

RAPD markers have been widely used in plant research for phylogenetic studies, genome mapping and genetic variation analysis both at intra - and inter-population levels (Li et al., 2008). The technique has several advantages including simplicity, low cost, speed and lack of requirement for DNA sequence information (Lopes et al., 2008). ISSR represents the marker of choice for varietal identification studies as they are transferable, hyper variable, highly polymorphic, multiallelic dominant markers, relatively simple to interpret and show high information content (Subramanian and Krishna 2004). There is a strong need to asses and document the extent of genetic diversity in naturally growing, systematically characterized plant populations to expedite its use in different germplasm related studies and breeding programmers. RAPD markers have been widely used for the identification of genetic relationship among populations (Afzal et al., 2004) and between plant populations (Ba et al., 2004). It is important to estimate the actual molecular genetic diversity of the existing plants to identify whether the lack of genetic variability might be the major constraining factor.

The present studies constitute the first successful attempt at assessment of genetic variability by DNA based molecular markers of intra and inter 
populations. The amplification profiles of two marker systems resulted in differences in the detected banding patterns. The level of polymorphism for each of the two markers systems was quite variable. The DNA polymorphisms were detected according to the presence and absence of bands. Absence of bands may be caused by failure of primers to anneal at a site in some individuals due to nucleotide sequence differences or by insertions or deletions between primer sites (Clark and Lanigan., 1993). RAPD and ISSR markers showed a high degree of similarity in dendrogram topologies, although with some differences, in the positioning of few individuals. Both markers aim to amplify a different region of the genome and thus it is reasonable that there are some fine differences between the two dendrograms based on an individual data set.

Several authors have used many molecular markers to moniter the plant genetic stability in in vitro regenerated plants in many species (Reddy et al., 2002) like Withania somnifera and Capparis deciduas (Tyagi et al., 2010). The plant regeneration in in vitro and re-introduction into natural habitat is one strategy for conservation of important plant species (Bhattacharyya et al., 2014, Roy et al., 2012). RAPD analysis in in vitro cultivation plants has reported in Rubiaceae family. The genetic diversity analysis in coffee species has reported (Mishra et al., 2011). RAPD and AFLP have major limitations like low reproducibility in RAPD, high cost of AFLP and the need to know flanking sequences is to develop species specific primers for SSR polymorphism (Reddy et al., 2002). ISSR-PCR is a technique that overcomes most of these limitations. Many people have used RAPD and ISSR markers to screen for genetic diversity in intra populations and inter populations (Goto et al., 1998, Sandeep et al., 2010). RAPD technique is extensively used to assess genetic variability generated by in vitro techniques (Chen et al., 1998, Devi et al., 2013, Khoddamzadeh, 2010). However, the successful assessment of RAPD profiles generated requires validation through repeated experiments. Thus, the degree of variability detected by RAPD technique needs to be crosschecked by using another marker system (Bhattacharyya et al., 2014).

Genetic diversity analysis of plant populations from other areas indicated that there is large genetic diversity among them. RAPD and ISSR marker analysis in Canthium parviflorum plants with their parents indicated that genetic diversity is lacking among them. Though Guntur parental plants are in sub cluster in dendrograms, but are inturn present in one major cluster along with tissue culture plants which confirms the less or no genetic variation in them. The prominent being the Canthium parviflorum plants collected from Kadapa district are present as separate cluster indicating that genetically they are different from others. For the first time, we report the genetic diversity analysis of in vitro regenerated plants, their wild parents and compared with different district plants of Canthium parviflorum. Diversity analysis of various plant populations living in different districts revealed that vast genetic diversity exists in different populations of Canthium parviflorum. The Canthium parviflorum plants of Kadapa district are present in the form of separate cluster differently from others indicating that genetically different from other plant populations. The same can be evidenced from distance matrix values of RAPD/ISSR data. The segregation of wild type of plants belonging into different areas into different sub clusters indicates the level and extent of genetic variation present in them.

Genetic diversity analysis by DNA based markers revealed that tissue culture plants are genetically similar to their wild plants with some variation. The usefulness of RAPD and ISSR markers and prevalence of genetic diversity in many plant populations has been demonstrated, our results correlated with previous reports (Smita et al., 2009, Yuan et al., 2009). This study has provided a longer number of reliable and reproducible finger printing profiles for sustainable management; linkage mapping, and genetic improvement of plants.

\section{Conclusions}

For the first time, we report the genetic diversity analysis of in vitro regenerated plants, their wild parents and compared with different district plants of Canthium parviflorum. Diversity analysis of various plant populations living in different districts revealed that vast genetic diversity exists in different populations of Canthium parviflorum. The Canthium parviflorum plants of Kadapa district are present in the form of separate cluster differently from others indicating that they are genetically different from other plant populations. Genetic diversity analysis by DNA based markers revealed that tissue culture plants are genetically similar to their wild plants with some variation.

\section{Acknowledgements}

The first author Dr. Sirigiri Chandra Kala is thankful to University Grants Commission, New Delhi for providing financial support with Rajiv Gandhi National Fellowship.

\section{References}

1. Afzal MA, Haque MM and Shanmugasundaram, S."Random Amplified Polymorphic DNA (RAPD) analysis of selected mungbean (Vigna radiaia L. Wilczek) cultivars". Asian J. Plant Sci. 3, (2004): 20 24.

2. Andrew, Clark and Caroline M Lanigan. "Prospects for Estimating Nucleotide Divergence with RAPDs." Molecular Biology and Evolution 10, 5 (1993): 1096-1111. 
3. Ayyanar M, Sankarasivaraman K and Ignacimuthu S. "Traditional Herbal Medicines used for the treatment of Diabetes among two major tribal groups in south Tamil Nadu, India." Ethnobotanical Leaflets 12 (2008): 276-280.

4. Ba FS, RS Pasquet and PM Gepts. "Genetic diversity in cowpea [Vigna aunguiculata (L.) Walp] revealed by RAPD markers." Genetic Resources and Crop Evol. 51(2004): 539-550.

5. Chen WH, Chen, TM, Fu YM, Hsieh RM, Chen WS. "Studies on somaclonal variation in Phalaenopsis." Plant Cell Rep. 18 (1998): 7-13.

6. Devi SP, Kumaria S, Rao SR, Tandon P. "In vitro propagation and assessment of clonal fidelity of Nepenthes khasiana Hook. f.: a medicinal insectivorous plant of India." Acta Physiol. Plant. 35 (2013): 2813-2820.

7. Ferreira WDM, Kerbauy, GB, Costa APP. "Micropropagation and genetic stability of a Dendrobium hybrid (Orchidaceae)." In vitro Cell Dev. Biol. Plant, 42 (2006): 568-571.

8. Goto S, Thakur RC, Ishii K. "Determination of genetic stability in long-term micropropagated shoots of Pinus thumbergii Parl. using RAPD markers." Plant Cell Rep. 18 (1998):193-197.

9. Hosagoudar VB \& GR Archana. "Host range of meliolaceous fungi in India." Journal of Threatened Taxa, 1 (2009): 269-282.

10. Khoddamzadeh AA. "Detection of somaclonal variation by random amplified polymorphic DNA analysis during micropropagation of Phalaenopsis bellina (Rchb. f.) Christenson.” African J. Biotechnol. 9 (2010): 6632-6639.

11. Kirtikar KR, and Basu BD. Lalit Mohan Basu, Allahabad, India, Indian Medicinal Plants.1 (2001): 3545.

12. Li F, Gan S, Weng Q, Zhao X, Huang S, Li M, Chen S, Wang Q, Shi F. "RAPD and morphological diversity among four populations of the tropical tree species Paramichelia baillonii (Pierre) Hu in China." Forest Ecology and Management. 255 (2008):1793-1801.

13. Lopes PM, Brito JM, Gomes S, Meirinhos J, Santos L, Pinto HG. "RAPD and ISSR molecular markers in Oleaeuropaea L.: Genetic variability and molecular cultivar identification." Genetic Resources and Crop Evolution. 54 (2007): 117- 128.

14. Manoj Kumar Mishra, Sandhyarani Nishani and Jayarama. "Molecular identification and genetic relationships among Coffee Species (Coffea L.) inferred from ISSR and RAPD Marker Analyses." Arch. Biol. Sci., Belgrade, 63 (2011): 667-679.

15. Murashige $\mathrm{T}$ and Skoog F. "A revised medium for rapid growth and bioassays with tobacco tissue cultures." Plant Physiol. 150 (1962): 473-497.
16. Murray MG, and Thompson WF. "Rapid isolation of high molecular weight plant DNA. Nuclei. Acids" Res. 8 (1980): 4321-5.

17. Nei M, and W H Li "Mathematical model for studying genetic variation in terms of restriction endonucleases." Proc Natl Acad Sci U S A. 76 (1979): 5269-5273.

18. Paromik Bhattacharyya, SumanKumaria, ReemavareenDiengdoh, PramodTandon. "Genetic stability and phytochemical analysis of the in vitro regenerated plants of Dendrobium nobile Lindl., an endangered medicinal orchid." Meta Gene 2 (2014): 489-504.

19. Pradeep Reddy M, Sarla N, \& EA Siddiq. "Inter simple sequence repeat (ISSR) polymorphism and its application in plant breeding." Euphytica 128(2002): 9-17.

20. Roy AR, Sajeev S, Pattanayak A, Deka BC. "TDZ induced micropropagation in Cymbidium giganteum Wall. Ex Lindl. And assessment of genetic variation in the regenerated plants." Plant Growth Regul. 68 (2012): 435-445.

21. Sandeep K, Yadav, Sumita Kachhawaha and SL Kothari. "Comparison of in vitro regeneration efficiency of leaf explants in response to different cytokinins and assessment of genetic uniformity of regenerated plants of Solanum surattence Burm.f." Intern. J. Biotechnol. 1,4 (2010): 097-103.

22. Sinha A, Jain R, Kachhwaha $\mathrm{S}$ and Kothari SL. "Optimization of the level of micronutrient copper in the culture medium improves shoot bud regeneration in Indian Ginseng [Withania somnifera (L.) Dunal]." Natl. Acad. Sci. Lett. (India). 33 (2010):11-16.

23. Subramanian J, and Gopala Krishna, J. "A comparative analysis of genetic diversity in blackgram genotype using RAPD and ISSR markers". TheorAppl Genet, 109 (2004):1687-1693.

24. Smita J, B Jugale, Leela, Bhosale, D. Trupti, Kad and $\mathrm{AB}$ Nadal. "Genetic diversity assessment in intra an inter populations of Xylocarpus granatum Koen. A critically endangered and narrowly distributed species of Maharastra." Curr. Sci., 97, 5 (2009): 695700.

25. Thomas JB, D Vijayan, SD Joshi, SJ Lopez and RR Kumar. "Genetic integrity of somaclonal variants in tea (Camellia sinensis (L.) O Kuntze as revealed by inter simple sequence repeats." J. Biotechnol., 123(2006):149-154.

26. Tyagi P, S Khanduja and SL Kothari. "In vitro culture of Capparis decidua and assessment of clonal fidelity of the regenerated plants." Biologia Plantarum., 54 (2010): 126-130.

27. Vigya Kesari, Vinod Madurai Sathyanarayana, Ajay Parida and LathaRangan. "Molecular marker-based characterization in candidate plus trees of Pongamia 
pinnata, a potential biodiesel legume." AoB plants (2010): plq017, doi:10.1093/aobpla/plq017

28. Warrier PK, VPK. Nambiar, and C. Raman Kutty. In: Indian Medicinal Plants, Orient Longman Publishers Ltd, Madras. Vol.I. (1994): 366.

29. Chandra Kala S, Mallikarjuna K and Aruna P "Qualitative Phytochemical Analysis of Seed and Leaf Callus Extracts of Canthium parviflorum Lam.' Guntur District, Andhra Pradesh. Int. J. Pharm. Bio. Sci. 3,4 (2012): 177-182.
30. Yuan XF, ZH Dai, XD Wang, B Zhao. “Assessment of genetic stability in tissue-cultured products and seedlings of Saussurea involucrata by RAPD and ISSR markers." Biotechnol. Lett. 31(2009): 1279-1287.

\section{Cite this article as:}

Sirigiri Chandra Kala, KVN Ratnakar Reddi, Akila Chandra Sekhar, Puli Chandra Obul Reddy, Kokkanti Mallikarjuna: Assessment of genetic diversity of Cantbium parviflorum Lam by RAPD and ISSR markers. Annals of Plant Sciences 6.11 (2017) pp. 1775-1783.

doi: $\underline{\text { http://dx.doi.org/10.21746/aps.2017.6.11.10 }}$

Source of support: Department of Botany \& Microbiology, Acharya Nagarjuna University, Andhra Pradesh, India.

Conflict of interest: Nil 